\title{
VISIBILITY AND HISTORY GIORGIO AGAMBEN AND THE EXEMPLARY
}

Steven D. DeCaroli

In the third chapter of The Coming Community, Giorgio Agamben turns his attention to the "example" insofar as it stands in relation to "the antinomy of the individual and the universal" that has its origin in language. The familiar antinomy to which Agamben refers arises when, in the act of calling something a tree, or a plow, or bitter, the empirical singularity of that thing is transformed into a member of a class defined by a property held in common. Language is forever positing the universal in place of, or as a substitute for, the singular that it wishes quite literally to keep in mind. "The word 'tree'," Agamben writes, "designates all trees indifferently, insofar as it posits the proper universal significance in place of singular, ineffable trees," and in so doing transforms singularities into members of a class. Language is perpetually caught between the universality of its generalized expressions and the empirical singularity of those denominated entities which, while they are the ultimate ground of this generalization, are always somehow inadequately represented by it.

The passage of an entity into language proceeds by way of a conceptualization which is familiar to philosophy, for in its most elementary form judgment (and here I am thinking of determinative judgment rather than reflective judgment) is the capacity to grasp the particular as an instance of a general rule-a relation Kant repeatedly describes as analogous to the application of a law. But the general categories which subsume particular objects remain fundamentally at odds with the irreducible singularity of the particular instances which language, and by extension thought, attempts to grasp. In Language and Death, Agamben ad-

PHILOSOPHY TODAY dresses this same process by referencing Hegel's discussion of sense-certainty in the opening chapter of the Phenomenology of Spirit. Here, sense-certainty's immediate encounter with being is compromised the moment consciousness attempts to speak this relation, that is to say, the moment language attempts to preserve sense-certainty's immediate relation to being it inevitably mediates that relation. ${ }^{3}$ Raw, unclassified being which is the object of sense-certainty is, therefore, abruptly transformed into the ideal being proper to language.

For Agamben, in Language and Death, in The Coming Community, and indeed, in his work as a whole, it is this moment of transformation from ineffable object to object of thought, and a host of other similarly structured transformations, that are of interest. More specifically, it is those instances where a transition gets hung-up, where it lingers on a threshold, where it hesitates and thereby reveals itself as purely transitional, that engages Agamben's attention. For it is in those case where an object is neither thoroughly inaccessible to cognition (and inaccessibility takes various forms, e.g., the noumenal, being-in-itself, chaos, etc.), nor thoroughly appropriated by cognition through its idealization in language, that Agamben identifies moments where the singular reveals itself in its singularity, that is to say, as something which is essentially un-common. For Agamben, it is in these hesitant moments of transition that unclaimed figures appearthe refugee, the werewolf, the sacred, the camp, Bartleby, and most germane to this discussion, the exemplary. In each case, essence is not a forgone conclusion. But despite the lack of an essential commonality,

SPEP SUPPLEMENT 2001 
what gathers each of these cases together is precisely their enduring potential to be otherwise: to be wolf, to be stateless, to be sacred, to be one who does not write.

When Agamben turns to demons, or to halos, to limbo, or to wolf-men, it is to suggest that when the human has lost its qualities it is most capable of forming a community which refuses any criteria of belonging. The task of the many brief, almost aphoristic chapters in The Coming Community is to begin to conceive of such a community, a community that lays no claim to identity, a community in which singularities, not bound by a common property, communicate nonetheless. And it is in pursuit of such singularities, that Agamben speaks of the example.

The example remains distinct, one singularity among others, while at the same time it stands in for them as a whole. The example, Agamben maintains, is one single case, but yet is called upon to stand in for a class of similar objects. In other words, the example is at one and the same time a member of a set and the defining criteria of that set. He writes,

One concept that escapes the antinomy of the universal and the particular has long been familiar to us: the example. In any context where it exerts its force, the example is characterized by the fact that it holds for all cases of the same type, and, at the same time, it is included among these. It is one singularity among others, which, however, stands for each of them and serves for all... Neither particular nor universal, the example is a singular object that presents itself as such, that shows its singularity. ${ }^{4}$

The example, it seems, possesses a capacity to indicate itself, to refer to itself, not through a conceptualization of its properties, but, as Agamben suggests, through an instructive showing. Thus, we are directed to the Greek word, para-digma, through which the example comes to mean that which liter- ally "shows alongside" itself. Or equally evocative, the German, Bei-spiel, literally that which "plays alongside" itself. ${ }^{5}$ The example provides its own criteria of inclusion and, therefore, remains ambiguously alongside the class of which it is most representative. In both of these etymological derivations the example is presented as the form of a singular object that remains neither fully included in a class nor full excluded from it. That is to say, it remains transitional.

If the pursuit of philosophy is traditionally for the a priori, and if the debates surrounding the a priori have largely been those waged between nominalist and realist, not over the necessity of the principles demonstrated, but over whether or not the categories that describe this necessity exist in reality or in name alone, then the example stands somewhat outside of this debate, not because it is not real or because it is not known by a name, but because it is not bound by the stability of a category-whether linguistic or actual. To say that Muhammad is a member of a class called prophet, or to say that the Farnese Hercules is a member of a class called beauty, may be true in a quite limited sense, but it certainly does not explain the potency these unique figures possess in their role as examples. Thus, while Agamben's discussion of the example is framed linguistically, even grammatically-illustrating how the example, in its singularity, epitomizes a conceptual category that it exceeds, and to which it does not quite belong-I will consider the example in a somewhat different context. Rather than attend to the linguistic appearance of the exemplary, I will concern myself with its historical manifestations and, in particular, I will consider the normative capacity that deeply characterizes the historical appearance of exemplary objects, individuals and events.

Whereas philosophy has traditionally placed an emphasis on necessity, pursuing the demonstrative validity of principles not contingent on time or place, seeking truths

\section{PHILOSOPHY TODAY}


unencumbered by historical ties, the example, by contrast, is fully historical. Its appearance in the form of an object, or an event, or a person-the Apollo Belvedere, for instance, or the French Revolution, or a Messiah-is both historical and irreducibly singular, yet each case very often assumes a powerful normative capacity. The question for much theoretical work, particularly in the areas of aesthetics and politics, but also for the philosophical historians of the eighteenth century and certainly in the more speculative work of religious traditionsThomas à Kempis's Imitation of Christ comes to mind-has been not only to recognize the normative potency of examples, but to determine how one ought to respond to them. Unlike moral rules or normative principles, what the example promises cannot be adequately legislated and, therefore, one's response to the exemplary cannot be a simple form of rational obedience-a mere adherence to reasonable principles. Debates in eighteenth-century aesthetics, for instance, are brimming with such considerations, particularly with respect to the cultivation of good taste. If, for instance, one teaches pupils how to paint by showing them masterworks, as opposed to demanding that they follow rigid rules or instructions, what prevents them from simply becoming proficient copyists? Or to borrow a theme from Kant's Critique of Judgment, taste cannot be legislated for it is never simply a matter of following a set of pre-given rules. As Kant remarks in the concluding paragraph of $\S 32$, it is for precisely this reason that "among all our abilities and talents, taste is ... what stands most in need of examples."

If, as Kant claims, taste functions not according to rules, but by way of examples, then, perhaps it is not surprising that, in the same thirty-second section of the Critique of Judgment, Kant also speaks of religion:

In religion, everyone must surely find the rule for conduct within himself . . . yet even here an example of virtue and holiness, set for us in history, will always accomplish more than any universal precepts we have received from priests or philosophers. ${ }^{7}$

My point here is certainly not to suggest that Kant has abandoned his commitment to the legislative function of reason or to the universal validity of the faculties, but rather, to suggest that there are moments even in Kant, particularly with respect to aesthetic judgment, where the work of abstract thought must give way to something more historical. And because even in Kant the historical appearance of an example is recognized as instrumental in acquiring a sense of taste, that is to say, in acquiring the ability to make sound judgments even when no general rule is at our disposal, it is worth considering the implications of this concept in more detail.

Consequently, I would like to take up this challenge by augmenting the work of Giorgio Agamben whose explicit writings on the exemplary, while limited and intermittent, are both evocative in their own right, and suggestive of a wider inquiry that, to the best of my knowledge, has not yet been realized-namely, a genealogy of the exemplary in Western thought. While such a project remains to be written, and will most certainly not be fully expounded here, in what follows I would nevertheless like to propose a manner in which this project might begin. In particular, I would like to suggest that there exists an abiding connection between Agamben's discussions of the exemplary as that which "shows its singularity" and instances in both eighteenth-century aesthetics and Renaissance humanism where similar statements are made regarding the exemplary, not only as a linguistic category, but as a form of pedagogy, that is, a mode of coming to knowledge, which more often than not, is employed for the sake of gathering a community: be it in religious traditions or aesthetic education.

In what follows, I will pay particular attention to how, in both aesthetic and histori-

\section{VISIBILITY AND HISTORY}


cal discourse, visibility, or rather a "showing," is closely associated with exemplarity. While this may be evident with respect to aesthetics, where beauty is by and large conceived of in terms of its physical appearance, and where in Kant we are told that the work of the genius "must be exemplary," it is less clear how history, which studies a past hidden by time, can also be grounded in the exemplarity of the visible. By tracing its usage back through eighteenth-century aesthetics, particularly in the art historical work of Johann Winckelmann, and ultimately to the Renaissance writings of Guarino da Verona, I intend to show that the meaning of the Greek concept of historia offers a way not only of reconciling history with visibility, but of contributing something to Agamben's philosophical project.

$$
* * * * *
$$

With the appearance of his muti-volumed History of Ancient Art, ${ }^{9}$ published in Rome in 1764, Johann Winckelmann's notoriety as an authority on classical art rapidly extended throughout Europe where he was regularly credited with being not only a founding figure of German neo-classicism, but the architect of a new method for understanding the art historical past. ${ }^{10}$ The opening lines of the History speak to Winckelmann's intention of erecting a new historical method opposed to the practices of traditional historians and, not uncharacteristically, the conceptual touchstone of this new method is retrieved from the classical past. What Winckelmann is expressly averse to are mere chronological synopsizes of events such as those biographical inventories of artist's lives that pack the manuscripts of traditional historians of art and say nothing about the stylistic maturation of the art work itself. What is missing from such works, and what Winckelmann strives to recuperate, is precisely that which is expressed in the Greek concept of historia, ${ }^{11}$ that is, the systemic quality of history which constructs from the factual record a meaningful arrangement and should not be misconstrued as being synonymous with the course of events itself. History in this sense, in the sense historia attests to, is on the order of a systematic science that extends beyond the mere reportage of facts. The system is given precedent over the individual facts because, so it is argued, the only way to understand the facts is through history as method. ${ }^{12}$ Winckelmann writes,

The History of Ancient Art which I have undertaken to write is not a mere chronicle of epochs, and of the changes that occurred within them. I use the term History [Geschichte] in the more extended signification that it has in the Greek language; it is my intention to present a system [Lehrgebäudes]. ${ }^{13}$

For the Greeks, historia connoted a manner of research, an investigation, or an inquiry, and for Herodotus, the first to develop the concept, historia was equally opposed to the mere factual recording of current events as it was to the effusive narrations of legends and myths. It was, in all likelihood, to Herodotus that Winckelmann turned for his conception of historia, due certainly to the fact that Herodotus was the first to use the term, but also, and more importantly, because unlike his slightly younger contemporary, Thucydides, Herodotus never doubted that events drawn from the distant past could be of appreciable value to the present. The facts of the past, however, do not offer themselves to the historian freely nor do they expose their meaning openly, rather their legibility is attained only through careful arrangement. In its classical sense, historia signifies precisely the task of constructing a system for guiding the arrangement of facts and it is in this capacity that historia represents a manner of knowing. The comprehension of facts and their capacity to be evidentiary transpires only in and through a system, that is to say, through what Winckelmann speaks of as a Lehrgebäude.

\section{PHILOSOPHY TODAY}


Etymologically, historia is a derivative of histèmi meaning to make a stand, to set up, or to institute. ${ }^{14}$ As such, Lehrgebäude, which Winckelmann likens to historia, ought to be understood in its instrumentality, for Winckelmann's historiography is no transparent medium for the conveyance of the past, nor is it a passive repository for facts, rather it is an artificial system set up by the historian to arrange facts in such as manner as to siphon knowledge from the past which would otherwise remain concealed. In this respect, historia is not to be understood as the bare discovery of knowledge, as if the historian is occupied with little more than finding and transmitting, but should be understood as the faithful extraction of knowledge from the past as it is filtered and interpreted through the historian's system (Lehrgebäude). This, at least, is the way historiography had been conceptualized by those who align the historian with the philosopher. History, like philosophy, actively crafts techniques for attaining knowledge, and it is in this sense that Winckelmann's return to the original meaning of historia, which places him squarely within the tradition of Renaissance humanism, ought to be seen not only as a challenge to traditional history, but as a critical rejoinder to philosophy as well. ${ }^{15}$

But historia has yet another etymological affiliation. Guarino da Verona, a humanist pedagogue and Greek scholar of the early Renaissance, alludes to this etymology in his Epistolario. ${ }^{16}$ After insisting that, "History. . . is a description of those things and times which our age sees or could see [Historia ... earum rerum et temporum descriptio est, quae nostra vidit aut videre potuit aetas]," Guarino rehearses the etymology of

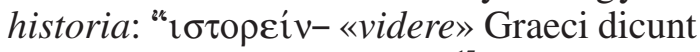

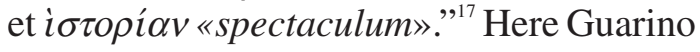
directly associates historia with visibility. In the Latin, videre, a declension of video, means simply to see or to observe, while spectaculum invokes the more public visibility of a show or a spectacle, but can equally refer to the seats flanking a theatrical stage or the bleachers of a circus. I raise this ancillary meaning of historia to emphasis the affinity history has with the empirical act of looking-something that Winckelmann's writings are frequently concerned with. During the Renaissance and particularly within the humanist tradition, in the works of scholars as well versed in classical Greek as Guarino, historia was conceived as a mode of knowing grounded in visibility. This is important for two reasons. First, because Winckelmann's own treatment of history, which emulates the antiquarian penchant for non-literary evidence, will hinge on the visibility of classical artifacts and the perceptibility of their subtle details, but also because the visibility historia invokes seems so antithetical to the project of history itself, i.e., the study of epochs which have long since dissolved into the shadows of antiquity. It is reasonable to surmise that the link between visibility and history is, even in the earliest discussions of historia, a consequence of the historian's empirical encounter with objectsprincipally with monuments and architectural ruins-which literally "show their age." It is this tradition of exploring the past by looking at it, rather than, say, by opening Pliny and reading what he has to say about his time, that Winckelmann is aligning himself with. This, in turn, is what makes systematicity, the Lehrgebäude, so essential. The visual, in the form of those non-literary sources favored by antiquarians, is not by nature chronological and so in order to understand it as such one must devise a system in which visibility folds into narration. The merging of visible details with chronology is ultimately what Winckelmann pursues under the concept of style. ${ }^{18}$

The spectaculum, the "seats of a theater" that lay in the etymological background of historia, calls particular attention to the role the theater played in Greek life. The theater, echoing the classical meaning of historia, was itself a way of knowing. It was an architecture designed for learning and for teach-

\section{VISIBILITY AND HISTORY}


ing those lessons that do not proceed by rational arguments-Aristotle's pidea finds its origin here- that is to say, those lessons one learns by example. The theatrical stage was a site for the display of the exemplary. It was a place for making things, typically the didactic narratives of mythology, visible to the members of the audience whose role as spectators was inseparable with their role as pupils. In Europe of the eighteenth century, spectatorship took on a different, but no less important form, when affluent Europeans embarked on the Grand Tour. An activity that was considered of paramount importance to a genteel education, the Grand Tour held out the promise that history, in the form of ancient artifacts and Roman buildings, could be directly experienced as a visible presence. ${ }^{19}$ "It was not, after all, the view of Greece as embodying absolute values that was new about Winckelmann's work," $\mathrm{M}$. Kay Flavell rightly points out, rather Winckelmann's originality consisted in "his intoxicating and novel demonstration that the past could be brought into a new and vibrant relation with the present through the shock of personal encounter with its art."20 Winckelmann's own project, which had so profound an impact on those European travelers who anticipated encountering in Rome both beauty and history, was therefore at least tacitly conceived of in terms of historia's alliance with vision and with the didactic potency of visible examples. While Guarino, speaking in the early fifteenth century, contends that "historical accounts surpass any image or statue because they give us spiritual and moral examples [imaginem statuamque praecellumt . . illi vero animos etiam effingunt et mores]," because "their voices ring over all the lands and the seas and they are found everywhere," ${ }^{21}$ Winckelmann argues that these very artifacts - the images and statues Guarino speaks of-when conceived in terms of history are just as exemplary as historical narratives because when understood properly, it is argued, they are inseparable from such narratives.

In its conventional usage the example is that which clarifies a point; it is that to which one points after a theory has been worked out in abstraction. Consequently, the example does not traditionally yield knowledge, it presupposes it. ${ }^{22}$ In both Guarino and Winckelmann the case is somewhat different, for in their writings the example exceeds its role as a mere case-in-point, such that when one encounters the exemplary it is as testimony, not as clarification. Through the example one learns something, one comes to knowledge in the manner of the witness, not through the abstractions of reason but through an empirical encounter. As Ernesto Grassi writes regarding Guarino's doctrina exemplorum,

Guarino takes an example to mean a "testimony" in the exact meaning of the word: we learn something not through abstract rational theory, but by being the "witness" to an "event." Examples are not isolated and abstract "images" of "ideas," but insights into the successful or failed response to an appeal which demands to be fulfilled "here" and "now." As such, the example is the contemplatio not of an abstract but of a concrete drama whose action takes place in history. . . . It is a 'putting-in-front-of-oureyes,' a recourse to historical 'evidence,' an 'indication. ${ }^{23}$

The tension within epistemology between the singular and the universal has considerable repercussions for theories of education with which both Guarino and Winckelmann were poignantly concerned. Imitation, as a practical response to encounters with the exemplary, immediately raises the question of how one can be expected to acquire from the singular example the components of truth without abolishing the singularity of the example by transforming it into a general concept-precisely the issue Agamben attempts to come to terms with by focusing his atten-

\section{PHILOSOPHY TODAY}


tion on the transitional moments wherein singularity gives way to general concepts. What is at issue in both Guarino and Winckelmann is an educational model that functions by means of indications and examples, not rational proofs. As Grassi notes, "Since the demands to which we must respond are always new, imitation cannot be considered a repetition," ${ }^{24}$ because such an understanding of imitatio would obligate a contradictory repetition of the singular. Rather, as both Guarino and Winckelmann suggest, every example must remain singular even as it demands, in its normative capacity as an example, both admiratio and imitatio. And when considering aesthetic education which, following Kant, does not uti- lize concepts, it is a non-conceptual pedagogical model that must be adopted; a model that, at least in Winckelmann, emerges from a distinctly historical understanding of the didactic potency of examples. Thus, what Grassi speaks of as history's capacity to "put-in-front-of-our-eyes" is not dissimilar from Winckelmann's own injunction addressed those who wish to know the beauty of the classical past, which he fluently expresses in his succinct injunction, "go hither and look." Here, borrowing from the Renaissance tradition of which Guarino is a part, and far from being a mere case-in-point, the examplum, in its singularity, comes first.

\section{ENDNOTES}

1. Giorgio Agamben, The Coming Community, trans. Michael Hardt (Minneapolis: University of Minnesota Press, 1993), p. 8.

2. Ibid.

3. Giorgio Agamben, Language and Death, trans. Karen E. Pinkus with Michael Hardt (Minneapolis: University of Minnesota Press, 1991), pp. 14-15.

4. Agamben, The Coming Community, p. 9. Emphasis added.

5. Ibid.

6. Immanuel Kant, Critique of Judgment, trans. Werner S. Pluhar (Indianapolis: Hackett Publishing, 1987), p. 147.

7. Ibid., p. 146. Translation slightly altered.

8. Ibid., p. 175.

9. Johann Joachim Winckelmann, Geschichte der Kunst des Alterthums, 4 vols. (Rome, 1764). The Geschichte was translated into French in 1766 and into Italian in 1779. It was, however, not fully translated into English until 1880, though the section on Greek art was available from 1849. I will be citing from a more recent German edition, Johann Joachim Winckelmann, Geschichte der Kunst des Altertums (Wien: Phaidon Verlag, 1934). I will also be referencing the most recent English translation, Johann Joachim Winckelmann, History of Ancient Art, trans.
G. Henry Lodge, 4 vols. (New York: Frederick Ungar Publishers, 1968).

10. The authoritative biography of Winckelmann remains Carl Justi's three volume work: Winckelmann und seine Zeitgennossen (Leipzig: F. C. W. Vogel, 1923), but there are numerous other accounts of Winckelmann's life. See, for instance, Wolfgang Leppmann, Winckelmann (New York: Alfred A. Knopf, 1970). For brief, though valuable summaries of Winckelmann's life see Elfriede Heyer and Roger C. Norton's introduction to their relatively recent English translation of the Gedanken, Reflections on the Imitation of the Greek Works in Painting and Sculpture (La Salle: Open Court, 1987); and even the chapter on Winckelmann in Walter Pater, The Renaissance: Studies in Art and Poetry (London: Macmillan, 1910). For a sustained study of the circumstance surrounding Winckelmann's untimely death and the long term public reaction to his murder see Lionel Gossman, "Death in Trieste," Journal of European Studies 22, no. 87 (1992): pp. 207-40.

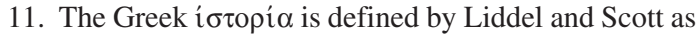
"a learning by inquiry" or "the knowledge so obtained." The emphasis is placed on the production of knowledge and not on mere chronicling. See H. G. Liddell and Scott, An Intermediate Greek-English

\section{VISIBILITY AND HISTORY}


Lexicon (Oxford: Oxford University Press, 1995), p. 385.

12. For more on Winckelmann's use of the Greek understanding of historia, see Marlite Halbertsma, "Johann Joachim Winckelmann and the History of Art as Deconstruction," Kunst and museumjournaal 3, no. 2 (1991): 24. Halbertsma writes: "In ancient times 'Historia' eventually took on the additional meaning of the story form used to relate events rather than the course of events. It was not until the last quarter of the eighteenth century, at least in German, that the term 'Geschichte' for history as a collection of events and 'Historie' for the account thereof became synonymous, and 'Geschichte' supplanted the word 'Historie'” (p. 24).

13. Winckelmann, Geschichte der Kunst des Altertums, p. 9; History of Ancient Art, p. 3.

14. For a discussion of this etymological derivation see Marlite Halbertsma, "Johann Joachim Winckelmann and the History of Art as Deconstruction," Kunst and museumjournaal 3, no. 2 (1991): 24. It should also be kept in mind that before the end of the eighteenth century the word Geschichte signified only a process and did not also indicate a collective noun. In Winckelmann's Geschichte der Kunst des Alterthums, for instance, Geschichte had not yet acquired the sense of a unified fact, i.e., history as such. In a useful footnote, Charles Bambach explains that "By 1800, the word no longer stood for a specific historical process . . . but began to be used apart from its genitivus objectivus as the history of the specific theme that it discusses. For the first time, die Geschichte is used in an abstract sense as a collective singular: history as such. Linguistically, Geschichte no longer refers merely to 'the history of $\mathrm{x}$ ' but to the process of all histories unified together as 'the' history of, for instance, the world (Weltgeschichte). With this shift in meaning, human reality begins to be grasped as part of an all-encompassing narrative process or pageant of teleological development." History, in other words, becomes a thing which is also a process. See Charles R. Bambach, Heidegger, Dilthey, and the Crisis of Historicism (Ithaca: Cornell University Press, 1995), p. 42.

15. For more on the significance of historiography in the Renaissance see Nancy S. Struever, The Language of History in the Renaissance: Rhetorical and Historical Consciousness in Florentine Humanism (Prince- ton: Princeton University Press, 1970); and Edmund B. Fryde, Humanism and Renaissance Historiography (London: The Hambledon Press, 1983). More specifically, and with respect to Renaissance aesthetics, a useful avenue of further study might address the writings of Leon Battista Alberti and in particular his writings on painting. See Leon Battista Alberti, On Painting and on Sculpture, trans. Cecil Grayson (London: Phaidon Press, 1972). For a study of this topic see Kristine Patz, 'Zum Begriff der 'Historia' in L. B. Albertis De Pictura," Zeitschrift für Kunstgeschichte 49, no. 3 (1986): 269-87.

16. Guarino da Verona traveled to Constantinople in 1388 to study Greek under Manuel Chrysoloars, the Constantinople born scholar who is considered the first to transplant Greek literature into Italy. He return to Italy where he taught Greek, authored Greek and Latin grammars, translated sections of Strabo and Plutarch, and helped to establish the texts of, among others, Livy and Pliny. For a fascinating discussion of Guarino da Verona on the significance of examples, a discussion from which I have borrowed much, see Ernesto Grassi, Renaissance Humanism: Studies in Philosophy and Poetics, trans. Walter F. Veit (Binghamton: Center for Medieval and Early Renaissance Studies, 1988), pp. 50-57.

17. Guarino da Verona, Epistolario, ed. R. Sabbadini, 3 vols. (Venezia, 1915-1919), Ep. 796 (II, 460), 73. Cited in Ernesto Grassi, Renaissance Humanism: Studies in Philosophy and Poetics, trans. Walter F. Veit (Binghamton: Center for Medieval and Early Renaissance Studies, 1988), p. 54. Translation is my own. The full passage, in which Guarino contrasts annals with histories, reads: "Ceterum quoniam historiae annaliumque orta mentio est, non erit absurdum utriusque vim aperire, «ut intelligatur quid sit id de quo disputetur». Historia, ut plerisque placet auctoribus, earum rerum et temporum descriptio est, quae nostra vidit aut videre potuit aetas; quod et vocabulum eiusque derivatio monatrat, siquidem.

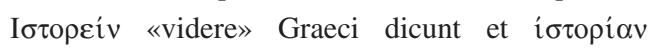
«spectaculum». Annales autem eorum annorum expositio qui a nostra remoti sunt aetate; licet alii aliter et sentiant et proferant et usus haec ipsa confundat."

18. On 28 January 1787, while in Rome viewing classical artifacts first hand, Goethe wrote with respect to Winckelmann's art historical project, "everyone who

\section{PHILOSOPHY TODAY}


takes the matter seriously can see that no judgment is possible in this field unless it can be developed historically." See Johann Wolfgang von Goethe, Italian Journey, trans. Robert R. Heitner (New York: Suhrkamp Publishers, 1989), p. 136.

19. On 13 December 1786, while on his own Grand Tour of Rome, Goethe had the unexpected opportunity to browse through letters Winckelmann wrote during his residency in Italy. Goethe singles out a passage from a letter Winckelmann wrote to Johann Michael Franke, the librarian who had worked with Winckelmann in Dresden, which Goethe quotes in his diary. Winckelmann's remarks read: "One has to be somewhat phlegmatic about looking for all the things in Rome, or else one is taken to be a Frenchman. Rome, I believe, is all the world's university, and I too have been tested and purified." Goethe continues with a comment on the passage, "These words correspond exactly with my way of investigating things here, and certainly, before coming to Rome, no one has a notion of how he will be schooled here. He must be, so to speak, reborn, and will look back on his former ideas as though they were children's shoes." See Goethe, Italian Journey, p. 122. Winckelmann's Italian letters are collected in Johann Joachim Winckelmann, Winckelmanns Briefe an seine
Freunde, ed. Karl Wilhelm Dassdorf, 2 vols. (Dresden, 1777-1780).

20. M. Kay Flavell, "Winckelmann and the German Enlightenment: On the Recovery and Uses of the Past," p. 89.

21. Guarino da Verona, Epistolario, ed. R. Sabbadini, 3 vols. (Venezia, 1915-1919), Ep. 706 (II, 310), 52. Cited in Grassi, Renaissance Humanism: Studies in Philosophy and Poetics, pp. 54-55. Here the entire passage reads: "Postremo si gloriae ut sic dicam instrumenta conferre libet, annales quamlibet imaginem statuamque praecellunt; hae siquidem corpora duntaxat, illi vero animos etiam effingunt et mores; hae mutae, illi voce sua terras implent et maria; hae paucis item in locis figi possunt, illi per universum terrarum orbem facile pervagantur disseminarique valent."

22. Ernesto Grassi, Renaissance Humanism: Studies in Philosophy and Poetics, p. 53.

23. Ibid. Grassi quotes Guarino da Verona on the notion that examples are testimonies, "illis vero testibus et exemplis ... instruatur et corroboretur." See da Verona, Epistolario, Ep. 676 (I, 261), 44.

24. Grassi, Renaissance Humanism: Studies in Philosophy and Poetics, p. 54.

Goucher College, Baltimore, 21204 